\title{
ANTIQUITY
}

need not be a true reflection of the wealth or status of the inhabitants. It is worth noting that the Saxon cemetery at Milton, only $65^{\circ} \mathrm{m}$. south of Mill Brook, produced rich jewellery (Peake, r93 I, Fig. 27), but it is not possible at present to associate these finds with one or indeed any parts of the Sutton Courtenay/ Drayton settlement complex.

Whatever the function and status of the individual sites within the complex, we can now point here to an intriguing geographical relationship between a range of different types of structure-Grubenhäuser, post-hole structures and large timber buildings, a relationship which should be elucidated by excavation. The discoveries must also be viewed against the background of the importance of the Upper Thames Valley at the time of the consolidation of the West Saxon monarchy in the later sixth century, and the continuing political importance of the region into the late seventh century. Work on relevant Saxon charters and on the later manorial boundaries and settlement patterns may help to elucidate problems of the cropmark evidence presented here. At the beginning of the Saxon period too, attention needs to be paid to the relationship of the complex to the nearby Drop Short Roman villa-a geographical relationship which is common to several Saxon and Roman sites in the Upper Thames Valley. Here Professor St Joseph has provided a new context within which Leeds's Sutton Courtenay site-once

\section{Pollen counts in North China}

Professor Richard Pearson of the Department of Anthropology and Sociology, University of British Columbia, has sent us the following note on pollen counts and the North Chinese neolithic environment. Professor Pearson has previously written for us 'Radiocarbon dates from China' $(I 973, I 4 I-3)$.

On the basis of remnants of natural vegetation, Wang (196r) has divided the vegetation of China into four major formations,- the montane boreal forest formation, the deciduous broadleaved forest formation, the evergreen broadleaved forest formation, and the grassland the archetype of a squalid Saxon village-can now be reviewed yet again.

DON BENSON and DAVID MILES

AVERY, M. and D. BRoWN. I972. Saxon features at Abingdon, Oxoniensia, xxxvIr, 66-81.

BENSON, D. and D. MILES. 1974. The Upper Thames Valley: an archaeological survey of the river gravels (Oxford).

HIRST, S. and P. RAHTz. Hatton Rock 1970, Birmingham E Warwickshire Archaeological Society Transactions, Lxxxv, 160-77.

LEEDS, E. T. 1923. A Saxon village at Sutton Courtenay, Berkshire (rst Report), Archaeologia, LXXIII, 146-92.

1927. A Saxon village at Sutton Courtenay, Berkshire (2nd Report), Archaeologia, Lxxvi, 59-80.

1934a. Recent Bronze Age discoveries in Berkshire and Oxfordshire, Antiquaries fournal, xIv, $264-76$.

I934b. Rectangular enclosures of the Bronze Age in the Upper Thames Valley, Antiquaries fournal, XIV, 4I4-I6.

1947. A Saxon village at Sutton Courtenay, Berkshire (3rd Report), Archaeologia, xcIr, 79-93.

PEAKE, H. I93I. The Archaeology of Berkshire (London).

RADFORD, C. A. R. 1957. The Saxon house: a review and some parallels, Medieval Archaeology, I, 27-38.

RAHTz, P. 1970. A possible Saxon Palace near Stratford-upon-Avon, Antiquity, XLIV, I 37-43.

ST JOSEPH, J. K. S. 1965. Air reconnaissance: recent results, Antiquity, xxxix, 60-4.

(ed.). I966. The Uses of Air Photography (London). 1972. Air reconnaissance: recent results, Antiquity, XLVI, I49-50.

desert formation. These are vegetation types, built on records of observations in many restricted areas. 'These generalized types embody the essential features of all of the individual observations but represent the exact conditions of none' (Wang, r96r, 9).

Early agricultural activity has been ascertained for two of the forest formations, the deciduous broadleaved and the evergreen broadleaved (Ueyama, 1969). Within these major formations, a number of vegetation types have been isolated, one of these being the deciduous broadleaved forest dominated by 


\section{NOTES AND NEWS}

oaks. This type, and the steppe grassland zone, converge along the best-known area of early neolithic occupation in China, which lies at the confluence of the Huang $\mathrm{Ho}$, the Fen $\mathrm{Ho}$, and the Weishui, where the provinces of Honan, Shensi, and Shansi come together (Chang, 1968, 85). Wang states that the plain 'was covered by broadleaved forest in the historical past' (1961, 80). Several variations of oak forest are recognized. The upper oak forests include Tilia, Acer, and Betula, and are closely related to the mixed hardwoods at higher elevations, while the lower oak forest is mixed with the common trees of the plain-Celtis, Hovenia, Pistacia, and Ulmus, suggesting that the lower forest may have once extended to the plain, which is now under cultivation (Wang, $196 \mathbf{r}$, 81 ). Wang states that the floor of the open oak forest is covered with coarse grasses .... and Artemisia ( $A$. sacrorum, $A$. mongolica, and $A$. lacinata var. briuscula)'. The early vegetation patterns of the loess highlands to the west, which is drier and higher than the areas to the east, are more problematical. Yi-fu Tuan points out that the dividing line between the steppe grassland and forest 'follows the Great Hsing-an mountains in the north, swings westward to the northern edge of the Wei Ho valley in central Shansi and southeastern Kansu, and continues southwestward to Tibet and southeast to Lhasa' (1969, 25). Yang Shao sites, from the map provided by Shih et al. $(1963,3)$ appear to straddle the boundary. The precise vegetation along the ecotone at that period of time is a topic of some debate, since it is now so completely altered by man. However, it appears that the eastern portions of the loess may have supported an open forest which extended down to the water courses.

A different view from the above is presented by Ping-ti Ho, who states: 'There can be little doubt that the loess highland area, except for its mountains, hills, slopes, and places near watercourses, has always been a non-wooded steppe' $(1969,9)$.

The basis for this statement lies in Ho's interpretation of palynological studies of loess deposits and the occurrences of references to Artemisia in ancient Chinese literary works.
Artemisia pollen is found to be the most abundant in samples taken from the $12 \mathrm{I}-\mathrm{m}$. deep loess profile at Wu Ch'eng, Shansi Province. From a chart published by Liu and Chang in Acta Geologica Sinica (1962, Fig. 2), Ho presents data showing that the frequency of Artemisia pollen, both throughout the whole profile and also in the top $20 \mathrm{~m}$., is more than 70 per cent of the total, and that arboreal pollen comprises only 33 grains out of $r, 003$ grains in the top $20 \mathrm{~m}$. of the profile. The total number of pollen grains considered is extremely small, and the distribution throughout the total cut is extremely sparse.

Since these conclusions about the environment are of great consequence in the interpretation of the adaptive changes which occurred in the development of the Chinese Neolithic, they deserve very careful scrutiny. A number of points should be made about the use of the palynological data.

I. The loess deposits are highly alkaline (Ho, 1969, 6). Alkaline soils are notably poor environments for the preservation of pollen grains. Loess is not considered an ideal sediment for the kind of studies mentioned above because of its rapid accumulation. In addition, Artemisia pollen has a particularly thick exine covering which may allow it to be preserved in higher percentages than other pollen grains which would be recoverable in an acid environment.

2. Professor Ho and the palynologists he cites have used 'raw' pollen counts, rather than relating them to the amounts of pollen produced by each group of genera. For instance, oak, which is a key genus in the discussion, is usually underrepresented in pollen spectra because of limited pollen production (Butzer, I971, 248).

3. The ecology of Artemisia must be taken into account. It is known to exist as a ground cover in open forests in North China, as noted above. Its presence does not necessarily indicate grassland.

4. One must consider Artemisia as a successional species. If one can rely on the ratios of pollen grain given by $\mathrm{Ho}$ as accurately reflecting any real environment, it may be observed that the proportional increases of Artemisia pollen coincide with the increases in the pollen of pine. 


\section{ANTIQUITY}

Evidence from North China (Wang, I 96I, 84) and central Korea (Kim, r968, 57) suggests that pine is secondary vegetation which takes over when primary deciduous forest is disturbed by humans. In the Korean case these data are not unequivocal: Oh (197I) refers to climatic causes for the increase in spruce and pine pollens (at an estimated date of $3,000 \pm 500$ years ago) rather than to anthropogenic factors; however, it seems to me that in both Korea and China the occurrence of pine and of Artemisia may be evidence of human disturbance of the forests. The increase in the pollen of the Chenopods noted by Ho $(1969,9)$ and Chou (Shih et al., $1963,271)$ are also indicators of human interference (Butzer, I971, 586). Generally it should be observed that no single pollen frequency should be taken as a type indicator separate from its ecological context. Pollen analysis without detailed ecological examination has been shown to be a risky endeavour. Human interaction with the environment must also be taken into account.

In my opinion, the case for a treeless steppe, even with the exception of the water courses and the mountain ridges, cannot be supported. There still seems to be evidence that at least part of the region was a deciduous, broadleaved forest dominated by oaks, admixed with small stands of ash, elm, and Chinese hackberry, with willows and poplars along the rivers (Tuan, I969, 27). Chang has reconstructed a 'more moist environment with a thicker vegetation ... with rising temperature and increased water distribution' (1970, 176) for the area during the time of the development of the Neolithic. Most writers agree that the earliest form of cultivation in this area was a form of slash-and-burn. This is favourably adapted to open forest-not to steppe grassland. The reconstruction of the environment is of utmost significance in the understanding of specific neolithic development in the Chung Yuan, and also for the comprehension of a worldwide model of food production development.

Acknowledgement is made to the Canada Council for support of research on prehistoric man-land relationships in East Asia, and to R. G. Matson and R. Mathews, who have offered criticisms and comments.

BUTZER, K. 1971. Environment and archaeology. and edition (Chicago).

Chang, K. C. 1968. Archaeology of Ancient China (Yale).

1970. The beginnings of agriculture in the Far East, ANTIQUITY, XLIX, $175-85$.

Hо, P. T. 1969. Loess and the origins of Chinese agriculture, American Historical Review, Lxxv, I, $1-36$.

KIM, C. M. 1968. The nutrient-holding capacity of soils of different forest types in Korea, Ecolological Review, XVII, 2, 67-74.

LIU, T. S. and T. Y. CHANG. I962. The Loess of China, Acta Geologica Sinica, XLII (in Chinese).

OH, C. Y. I97I. A pollen analysis of peat sediments of Pyung-Taek County, Korea, Korean Yournal of Botany, xv, 3, 126-33 (in Korean).

sHIH, H. P. et al. 1963. Hsi-an pan p'o (Peking), (in Chinese).

TUAN, Y. F. 1969. China (Chicago).

UEYAMA, SHINPEI. 1969. The culture of the broadleaf evergreen forest zone (in Japanese).

WaNG, c. W. 1961. The forests of China, with a survey of grassland and desert vegetation. Maria Moors Cabot Foundation Publication No. 5 (Harvard).

\section{Drought and the decline of Mycenae: some comments}

Dr Oliver Dickinson, of the Department of Ancient History and Archaeology in the University of Birmingham, sends these comments on the article, 'Drought and the decline of Mycenae' by R. A. Bryson, H. H. Lamb and David L. Donley (I974, 46-5O). Professor Bryson replies on behalf of himself and his colleagues.

Archaeologists are often urged nowadays to show caution in their handling of scientific evidence; it is surely not too much to expect scientists to show equal care with archaeological evidence. In this respect, 'Drought and the decline of Mycenae' (Antiquity, 1974, 46-50) sets a bad example. The authors appear to have relied for an account of the archaeological evidence on a secondary work published several years ago by a scholar who is not a specialist in the field; they give no indication of expecting that any new evidence might have appeared since then, and their bibliography includes none of the absolutely basic work of $\mathrm{V}$. R. Desborough and A. M. Snodgrass. As a result, 